\title{
ROAD THICKNESS ANALYSIS USING MDP METHOD 2017 (CASE: PURWODADI - NONGKOJAJAR)
}

\author{
Ratna Handayani ${ }^{1}$, Ahmad Faathir Wicaksono ${ }^{2}$ \\ 1,2 Junior Road and Bridge Engineer, East Java Province Road Agency, Surabaya, Indonesia \\ e-mail: ratnay1999@gmail.com
}

\begin{abstract}
Purwodadi - Nongkojajar road section is one of the East Java Province roads in UPT PJJ Probolinggo, which received funding from the Regional Road Grant Program (PHJD). From the results of the road condition survey in 2020, the condition of road damage in the form of holes and hair cracks was obtained. Based on this, it was necessary planning the thickness of the re-pavement or overlay. This program begins with inventory and road condition, topographic and soil investigation surveys. From the results of the topographic survey, we can measure the slope, then we conduct an investigative survey using Benkelman-beam deflection measure tool to determine the back-deflection value. References and secondary data of traffic growth and road class data are collected. The thickness of the pavement was calculated using the MDP 2017 method. This research found that the required layer was $A C$-WC layer with an expected thickness of $4 \mathrm{~cm}$. Due to the uneven condition of the existing road, an additional leveling layer $A C-B C$ was needed to overcome this condition with a thickness of $3.0 \mathrm{~cm}$.
\end{abstract}

Keywords: Road Pavement; Pavement Thickness; Benkelman Beam; MDP

\section{Introduction}

Roads are the most widely used transportation infrastructure by people of Indonesia to carry out daily mobility, with the increasing flow of vehicles passing a road segment, it will affect the carrying capacity of the soil as the foundation layer of the road [1]. Roads that have high traffic flow and heavy traffic loads must be balanced by good pavement conditions [2]. One of them is Jalan Purwodadi - Nongkojajar. Planning for overlay or overlay thickness in Indonesia generally uses the deflection value using the Benkelman Beam equipment [3][4]. Based on Bina Marga, 2005, Benkelman Beam test is a tool used to measure reverse deflection, direct deflection and pavement inflection points which describe the strength of the road pavement structure. The use of this tool is very effective in determining the strength of the structure without causing damage to the road surface [5]. From the test results will be obtained the value of maximum back deflection, turning point back deflection and concave deflection [6]. Based on the results of the road condition survey, the Purwodadi- Nongkojajar road section has suffered damage in the form of cracks and holes in several parts. Therefore, it is necessary to re-coating or overlaying. This pavement thickness planning uses the 2017 MDP method [7][8]. 

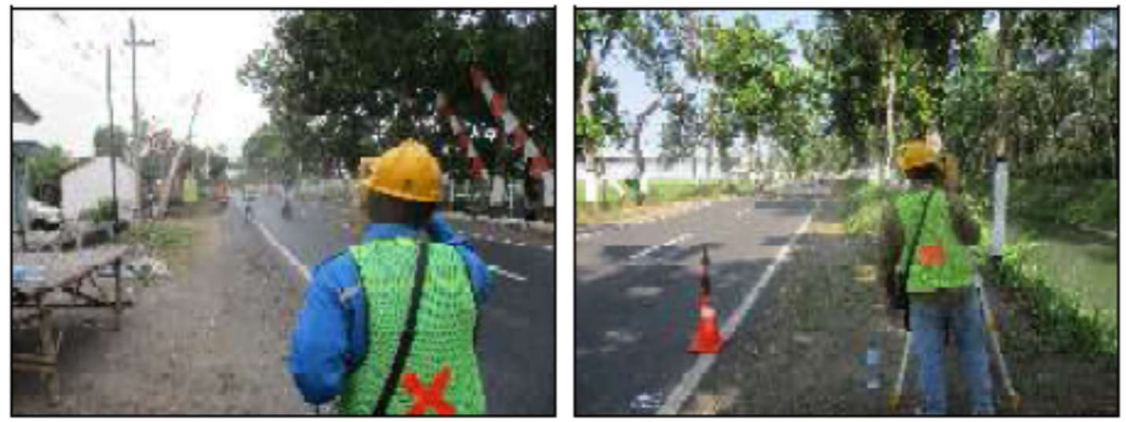

Figure 1. Inventory Survey Documentation

\section{Material and Methods}

\subsection{Material}

The basis of the flexible pavement design procedure with asphalt mixture used in this manual is the mechanical characteristics of the material and the mechanistic analysis of the pavement structure. This method relates the input in the form of wheel load, pavement structure and mechanical properties of the material, with the output in the form of pavement response to wheel loads such as stress, strain or deflection [12].

The structural response is used to predict the performance of the pavement structure in terms of permanent deformation and fatigue cracking. Because the prediction is based on performance material in the laboratory and observations in the field, this approach is also known as the empirical mechanistic method. The main advantage of the mechanistic design method is that it is possible to analyze the effects of changes in design inputs, such as changes in material and traffic loads, quickly and rationally. A number of advantages of this method compared to purely empirical methods include:

1. Can be used analytically to evaluate changes or variations in vehicle load on pavement performance.

2. Pavement performance with new materials can be evaluated based on the mechanical properties of the materials concerned.

3. Can be used to analyze the effect of changes in material properties due to environment and climate on pavement performance.

4. Evaluate pavement response in relation to specific pavement damage modes (fatigue cracking and permanent deformation).

In general, the pavement structure model used in this manual is a multi-layer structure which is linearly elastic, isotropic (for bounded material) and anisotropic for unbounded material, the CTB layer is considered to have cracked (post cracking condition) [8][2].

For isotropic materials the two elastic parameters used are the elastic modulus $\mathrm{E}$ and the Poisson ratio. For cross-anisotropic materials, 5 elastic parameters are needed, namely Ev, Eh, vh, hh and shear modulus f. Where Ev and Eh are the modulus in the vertical and horizontal directions, respectively. The parameters vh and hh are Poisson's ratios in the vertical direction due to the horizontal, respectively. For practical reasons, the Poisson ratio in both directions is assumed to be identical.

The non-linear characteristic of granular material is approximated by dividing the granular layer into several layers with different modulus E.

\subsection{Method}

Research Location was in the Purwodadi - Nongkojajar Section $(\mathrm{Km} .76+552-78+718)$ in the Pasuruan Regency area. The length of Purwodadi - Nongkojajar road is $20.945 \mathrm{Km}$ and the width is various from 6-7 m. 


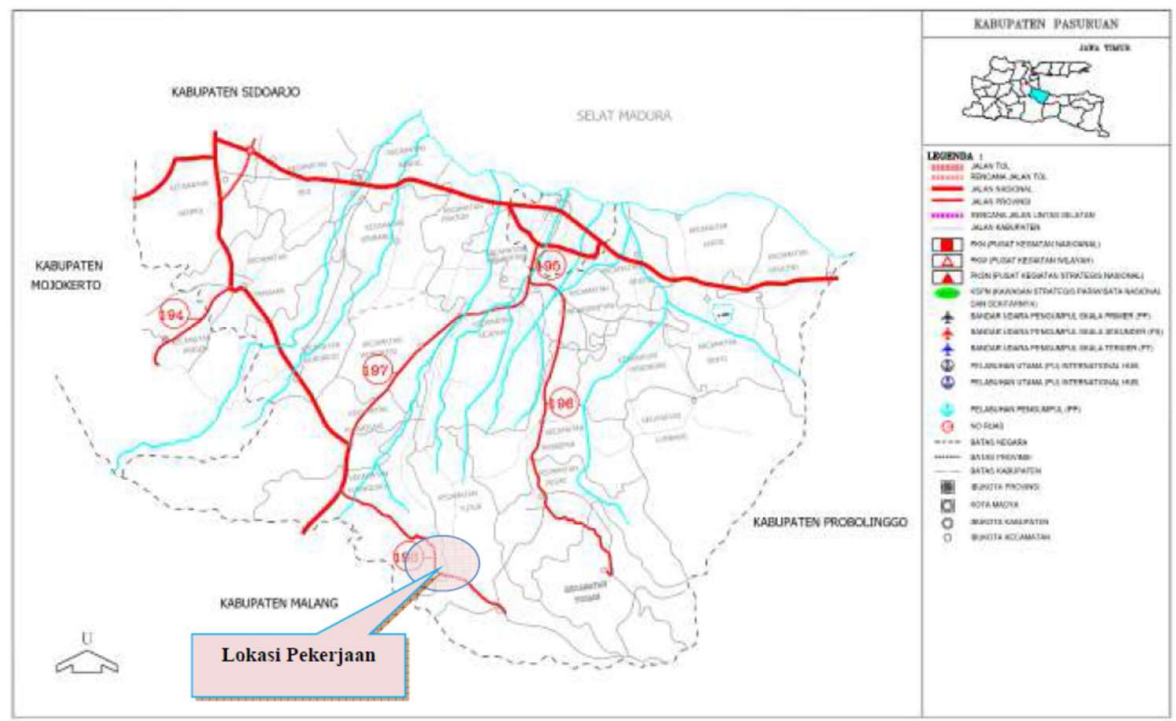

Figure 2. Location of Study

(Source: Road Function and Status Book, 2016)

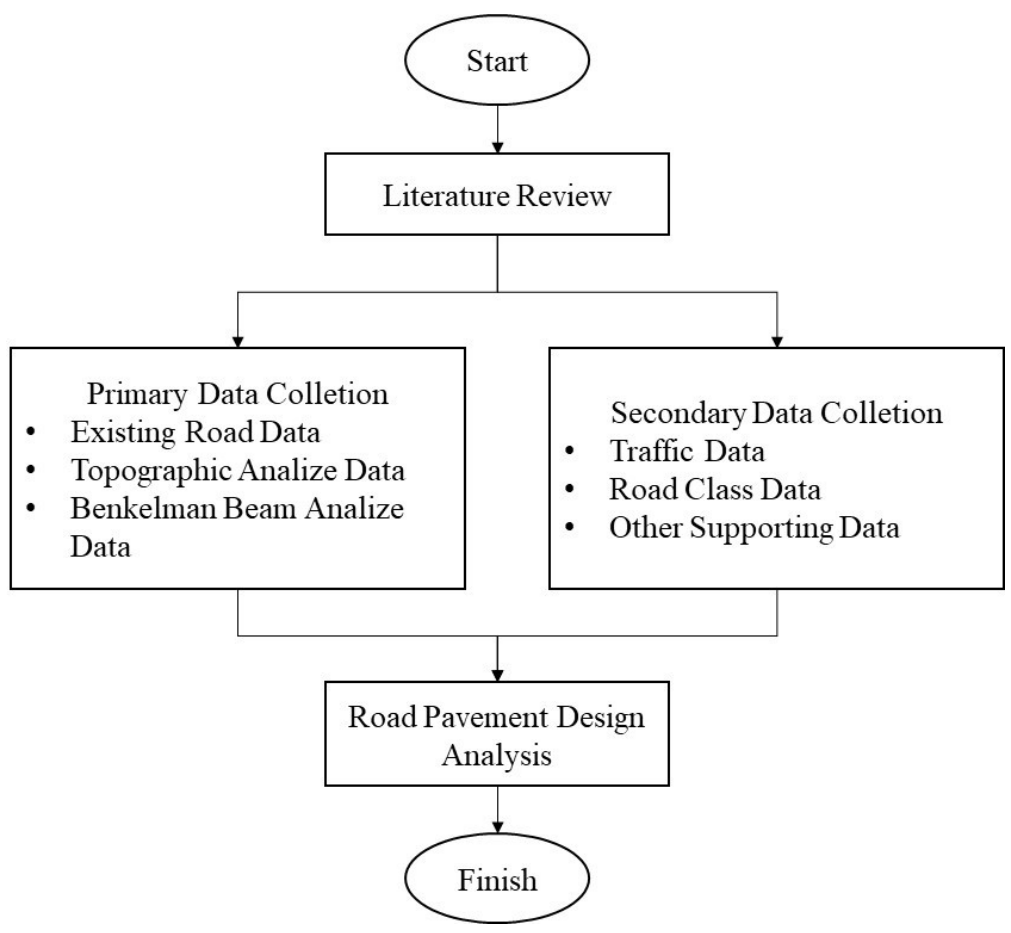

Figure 3. Flow Chart Research

1. Primary Data is the main data, data obtained from direct measurements and observations in the field at the research location.

2. Secondary Data is data obtained indirectly, or data obtained from related agencies. 
The deflection data analysis was carried out to process the deflection data from the Benkelman Beam test results in the field so that this deflection data could be used as a parameter in the process of determining the overlay thickness. From the data for each segment, it will be processed and produce representative deflection data and design/permitted deflection data. These two data become the parameters used to determine the thickness of the added layer. In the analysis, not all data from the Benkelman Beam (BB) survey will be used, this is because it is related to the uniformity factor.

\section{Result and Discussion}

\subsection{Road Existing Data}
a. Width of pavement
$: 5-6$ metre
b. Width of shoulder
$: 0,8-1.3$ metre
c. Topographic Condition
: slope $4,06 \%$ (flat)

\subsection{Traffic Analysis}

Cumulative Equivalent Single Axle Load (CESA) is the cumulative amount of the design traffic axle load on the plan lane for the life of the plan [12]. In relation to the pavement analysis method used, namely the planning of the additional layer of flexible pavement with the deflection method (Benkelman Beam), the traffic analysis is calculated using VDF4 and VDF5 to obtain ESA4 and ESA5 [9]. Traffic data analysis refers to the Road Pavement Design Manual No.02/M/BM/2017. The VDF value used is in accordance with Table $1 \mathrm{VDF}$ value for each type of commercial vehicle.

The data needed in the analysis were as follows:

- Road type

- Traffic increase (i)

- Lifetime planned (n)

- Directional distribution factor (DD)

- Lane distribution factor (DL)
$: 2 / 2$ UD

: 3,5\% (Table 4.1 MDP 2017)

: 10 tahun (Table 2.1 MDP 2017)

$: 0,5$

: 1 (Table 4.2 MDP 2017)

Table 1. Estimated Cumulative Traffic Load

\begin{tabular}{|c|c|c|c|c|c|c|c|c|c|}
\hline \multirow{2}{*}{$\begin{array}{c}\text { Vehicle } \\
\text { Type }\end{array}$} & \multirow{2}{*}{ AADT } & \multicolumn{2}{|c|}{ VDF } & i & $\mathrm{n}$ & DD & DL & ESA 4 & ESA 5 \\
\cline { 2 - 10 } & & VDF 4 & VDF 5 & & & & & & 10 \\
\hline 1 & 2 & 3 & 4 & 5 & 6 & 7 & 8 & 9 & 0 \\
\hline Group 1 & 6.485 & 0 & 0 & $3.5 \%$ & 10 & 0.5 & 1 & 0 & 0 \\
\hline Group 2 & 151 & 0 & 0 & $3.5 \%$ & 10 & 0.5 & 1 & 0 & 0 \\
\hline Group 3 & 772 & 0 & 0 & $3.5 \%$ & 10 & 0.5 & 1 & 0 & 0 \\
\hline Group 4 & 661 & 0 & 0 & $3.5 \%$ & 10 & 0.5 & 1 & 0 & 0 \\
\hline Group 5a & 0 & 0 & 0 & $3.5 \%$ & 10 & 0.5 & 1 & 0 & 0 \\
\hline Group 5b & 6 & 1 & 1 & $3.5 \%$ & 10 & 0.5 & 1 & $13.167,02$ & $13.167,02$ \\
\hline Group 6a & 414 & 0,55 & 0,5 & $3.5 \%$ & 10 & 0.5 & 1 & $487.018,18$ & $442.743,80$ \\
\hline Group 6b & 0 & 4 & 5.1 & $3.5 \%$ & 10 & 0.5 & 1 & 0 & 0 \\
\hline Group 7a & 0 & 4.7 & 6.4 & $3.5 \%$ & 10 & 0.5 & 1 & 0 & 0 \\
\hline Group 7b & 0 & 12.6 & 17.8 & $3.5 \%$ & 10 & 0.5 & 1 & 0 & 0 \\
\hline Group 7c c & 0 & 7.4 & 9.7 & $3.5 \%$ & 10 & 0.5 & 1 & 0 & 0 \\
\hline Group 8 & 3 & 0 & 0 & $3.5 \%$ & 10 & 0.5 & 1 & 0 & 0 \\
\hline
\end{tabular}

Based on the table above, the CESA (Cumulative Equivalent Single Axle) values during the design life are 500,185.21 ESA4 and 455,910.83 ESA5.

\subsection{Topographical Data Analysis}

Topographical data [10] and analysis are used in th e description of the situation map [11], where the situation map is drawn per $350 \mathrm{~m}$ and is attached to a picture album with the title "situation and 
longitudinal sections". From the results of data collection carried out through field surveys, the results of topographic data analysis are obtained as follows:

Table 2. Topographic Data

\begin{tabular}{|c|c|c|c|c|c|c|}
\hline $\begin{array}{c}\text { Location } \\
(\mathrm{km})\end{array}$ & Topographic Data & Elevation & $\begin{array}{c}\text { Distance } \\
(\mathrm{m})\end{array}$ & $\begin{array}{c}\text { height } \\
\text { difference }\end{array}$ & Slope & Description \\
\hline $076+552-$ & Max Elevation & 863,701 & $2.136,00$ & 86,680 & $4,06 \%$ & flat \\
\cline { 2 - 5 } $078+718$ & Min Elevation & 777,021 & & & \\
\hline
\end{tabular}

Source: Data Analysis, 2020

\subsection{Bankelmen Beam Data Analysis (Deflection)}

Table 3. Left Side Deflection Calculation

\begin{tabular}{|c|c|c|c|c|c|c|c|c|c|c|c|c|c|}
\hline \multirow{2}{*}{$\begin{array}{l}\text { Km } \\
\text { (left) }\end{array}$} & \multicolumn{5}{|c|}{ Temperature $^{\circ} \mathrm{C}(\mathrm{d}=10 \mathrm{~cm})$} & \multirow[t]{2}{*}{$\mathrm{ft}$} & \multirow[t]{2}{*}{$\mathrm{Ca}$} & \multirow{2}{*}{$\begin{array}{c}\mathrm{d}(\mathrm{mm}) \\
\text { Do }\end{array}$} & \multirow[t]{2}{*}{ FKa-bb } & \multirow{2}{*}{$\begin{array}{c}\mathrm{dB}(\mathrm{mm}) \\
\mathrm{D} 0\end{array}$} & \multirow[t]{2}{*}{ dB2 } & \multirow{2}{*}{$\begin{array}{c}\mathrm{D}(\mathrm{mm}) \\
\mathrm{D} 200\end{array}$} & \multirow{2}{*}{$\begin{array}{c}\mathrm{dB}(\mathrm{mm}) \\
\mathrm{D} 0-\mathrm{D} 200\end{array}$} \\
\hline & tu & tp & $\mathrm{tt}$ & tb & $\mathrm{tl}$ & & & & & & & & \\
\hline $78+600$ & 28 & 29 & 32.3 & 28.6 & 30 & 1.126 & 1.2 & 0.84 & 1.13 & 1.28 & 1.65 & 0.66 & 1.01 \\
\hline $78+500$ & 28 & 29 & 32.3 & 28.6 & 30 & 1.126 & 1.2 & 0.76 & 1.13 & 1.16 & 1.35 & 0.52 & 0.79 \\
\hline $78+100$ & 27 & 28 & 31.2 & 27.6 & 28.9 & 1.156 & 1.2 & 0.5 & 1.13 & 0.78 & 0.62 & 0.44 & 0.69 \\
\hline $77+700$ & 27 & 27 & 30.6 & 27.1 & 28.2 & 1.178 & 1.2 & 0.5 & 1.13 & 0.8 & 0.64 & 0.39 & 0.62 \\
\hline $77+500$ & 26 & 27 & 30 & 26.7 & 27.9 & 1.188 & 1.2 & 0.98 & 1.13 & 1.58 & 2.5 & 0.8 & 1.29 \\
\hline $77+400$ & 26 & 27 & 30 & 26.7 & 27.9 & 1.188 & 1.2 & 0.64 & 1.13 & 1.03 & 1.06 & 0.5 & 0.81 \\
\hline $77+300$ & 26 & 27 & 30 & 26.7 & 27.9 & 1.188 & 1.2 & 0.46 & 1.13 & 0.74 & 0.55 & 0.38 & 0.61 \\
\hline $76+800$ & 26 & 26 & 29.5 & 26.2 & 27.2 & 1.210 & 1.2 & 0.46 & 1.13 & 0.76 & 0.57 & 0.35 & 0.57 \\
\hline
\end{tabular}

Source: Data Analysis, 2020

Table 4. Right Side Deflection Analysis

\begin{tabular}{|c|c|c|c|c|c|c|c|c|c|c|c|c|c|}
\hline \multirow{2}{*}{$\begin{array}{l}\text { Km } \\
\text { (left) }\end{array}$} & \multicolumn{5}{|c|}{ Temperature $^{\circ} \mathrm{C}(\mathrm{d}=10 \mathrm{~cm})$} & \multirow[t]{2}{*}{$\mathrm{ft}$} & \multirow[t]{2}{*}{$\mathrm{Ca}$} & \multirow{2}{*}{$\begin{array}{c}\mathrm{d}(\mathrm{mm}) \\
\text { Do }\end{array}$} & \multirow[t]{2}{*}{ FKa-bb } & \multirow{2}{*}{$\begin{array}{c}\mathrm{dB}(\mathrm{mm}) \\
\mathrm{D} 0\end{array}$} & \multirow[t]{2}{*}{$\mathrm{dB} 2$} & \multirow{2}{*}{$\begin{array}{c}\mathrm{D}(\mathrm{mm}) \\
\mathrm{D} 200\end{array}$} & \multirow{2}{*}{$\begin{array}{l}\text { dB(mm) } \\
\text { D0-D200 }\end{array}$} \\
\hline & tu & tp & $\mathrm{tt}$ & tb & tl & & & & & & & & \\
\hline $78+600$ & 28 & 29 & 32.3 & 28.6 & 30 & 1.126 & 1.2 & 0.52 & 1.13 & 0.79 & 0.63 & 0.38 & 0.58 \\
\hline $78+500$ & 28 & 29 & 32.3 & 28.6 & 30 & 1.126 & 1.2 & 0.9 & 1.13 & 1.37 & 1.89 & 0.85 & 1.3 \\
\hline $78+400$ & 28 & 28 & 31.7 & 27.6 & 29.3 & 1.146 & 1.2 & 0.8 & 1.13 & 1.24 & 1.55 & 0.75 & 1.17 \\
\hline $77+900$ & 27 & 27 & 30.6 & 27.1 & 28.2 & 1.178 & 1.2 & 0.48 & 1.13 & 0.77 & 0.59 & 0.46 & 0.74 \\
\hline $77+700$ & 27 & 27 & 30.6 & 27.1 & 28.2 & 1.178 & 1.2 & 0.52 & 1.13 & 0.83 & 0.69 & 0.47 & 0.75 \\
\hline $77+600$ & 27 & 27 & 30.6 & 27.1 & 28.2 & 1.178 & 1.2 & 0.98 & 1.13 & 1.57 & 2.45 & 0.93 & 1.49 \\
\hline $77+500$ & 26 & 27 & 30 & 26.7 & 27.9 & 1.188 & 1.2 & 0.44 & 1.13 & 0.71 & 0.5 & 0.4 & 0.64 \\
\hline $77+300$ & 26 & 27 & 30 & 26.7 & 27.9 & 1.188 & 1.2 & 0.48 & 1.13 & 0.77 & 0.6 & 0.43 & 0.69 \\
\hline $77+100$ & 26 & 26 & 29.5 & 26.2 & 27.2 & 1.210 & 1.2 & 0.6 & 1.13 & 0.99 & 0.97 & 0.52 & 0.85 \\
\hline & & & & & & & & & Jumlah & 17.18 & 18.80 & 9.23 & 14.61 \\
\hline
\end{tabular}

Source: Data Analysis, 2020 


\subsection{Determination of Pavement Thickness Based on Deflection Data}

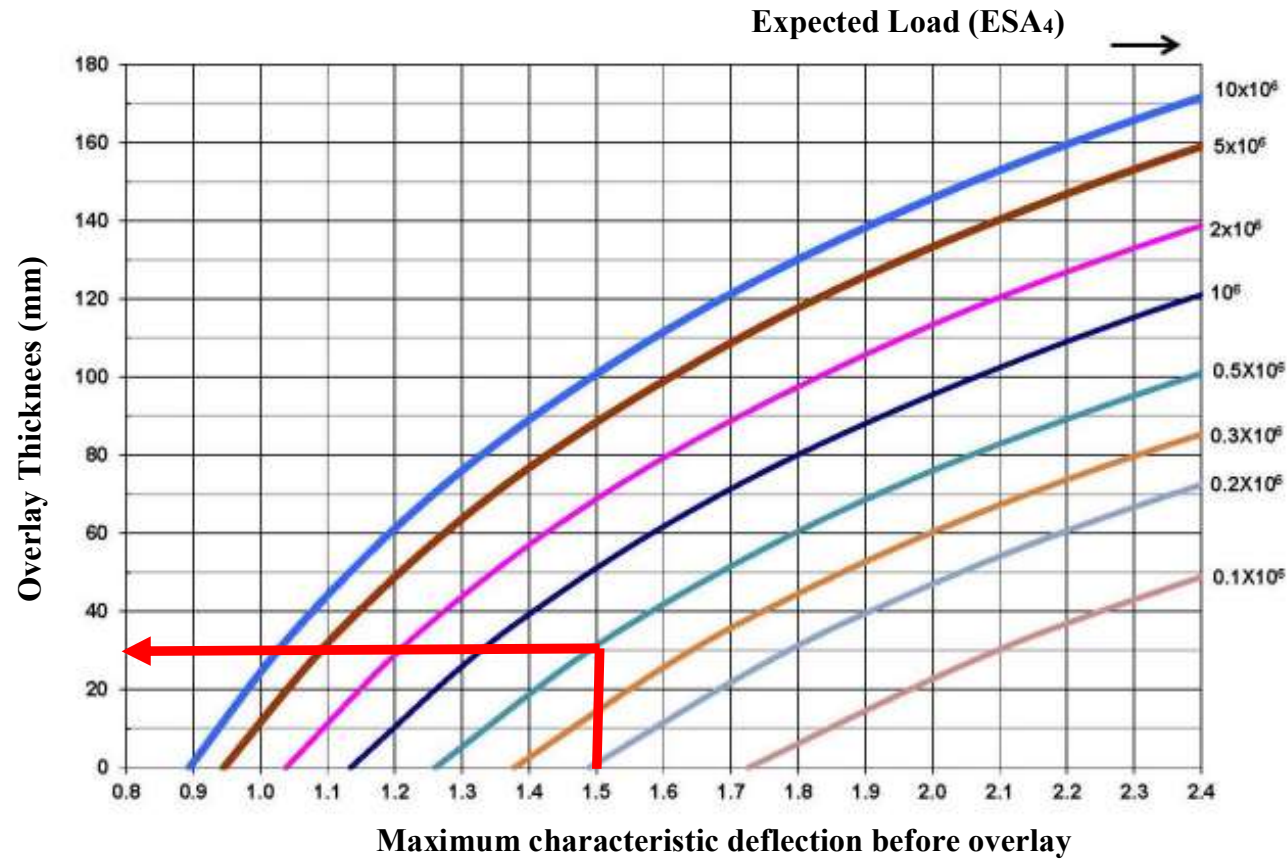

Figure 4. Overlay Based on Benkelman Beam Deflection

Calculation of the thickness of the flexible pavement using the Planning Guidelines for Adding Flexible Pavement Layers with the Deflection Method (Pd T-05-2005) and the Road Pavement Design Manual no. 02/M/BM/2017.

With a D representative value of $1.50 \mathrm{~mm}$ and a design load of 500,176.001 ESA4, it can be obtained that the overlay thickness as shown in Figure 3 is $40 \mathrm{~mm}$. Determination of overlay thickness cannot use the Conventional Asphalt Thin Overlay Thickness graph to Prevent Fatigue Cracking at WMAPT $>350 \mathrm{C}$ because the D0-D200 value is too small, so it cannot be displayed in the graph. From the analysis of the overlay thickness based on the Benkelman Beam (BB) back deflection, a single layer AC-WC overlay with a thickness of $4 \mathrm{~cm}$ was used. Due to the uneven condition of the existing road, an additional leveling layer is needed to handle this condition, so an $\mathrm{AC}-\mathrm{BC}$ grader with a thickness of $3.0 \mathrm{~cm}$ is used.

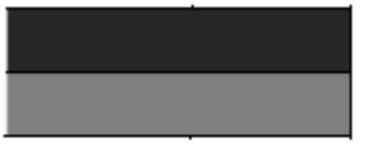

$$
\begin{array}{ll}
\mathrm{AC}-\mathrm{WC} & =4 \mathrm{CM} \\
\mathrm{AC}-\mathrm{BC} \text { (Levelling) } & \geq 3 \mathrm{CM}
\end{array}
$$

Figure 5. Road Pavement Sketch

\subsection{Determining the Structure of Road Widening}

On the planned road sections, the existing road width does not meet the standards, therefore road widening is required. The width of the existing road ranges from $5.0-6 \mathrm{~m}$, so it is widened to $6 \mathrm{~m}$. The pavement sketch for road widening is shown in the following figure. 


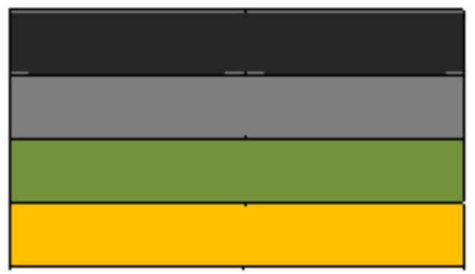
1. $\mathrm{AC}-\mathrm{WC}$ $=4 \mathrm{~cm}$
2. $\mathrm{AC}-\mathrm{BC}$ (levelling) $\geq 3 \mathrm{~cm}$
3. fc' (existing)
$=30 \mathrm{~cm}$
Base Soil

Figure 6. Road Widening Pavement Sketch

\section{Conclusion and Suggestion}

Based on the data and calculations that have been carried out, the following conclusions are obtained:

a. Flexible pavement thickness for overlay

$\begin{array}{ll}\mathrm{AC}-\mathrm{WC} & =4,0 \mathrm{~cm} \\ \mathrm{AC}-\mathrm{BC} \text { (levelling) } & =3,0 \mathrm{~cm}\end{array}$

b. Pavement structure for road widening

$\mathrm{AC}-\mathrm{WC} \quad=4,0 \mathrm{~cm}$

AC-BC (levelling) $=3,0 \mathrm{~cm}$

Existing concrete

\section{References}

[1] S. Sudarno, L. Fadhilah, A. Afif, S. Nurobingatun, H. Hariyadi, and A. Mufid, "Analisis Tebal Perkerasan Jalan Raya Magelang-Purworejo Km 8 Sampai Km 9 Menggunakan Metode Bina Marga 1987," Rev. Civ. Eng., vol. 2, no. 1, pp. 41-46, 2018, doi: 10.31002/rice.v2i1.689.

[2] A. A. Anisarida, E. Hafudiansyah, and E. Kurniawan, "Perencanaan Tebal Perkerasan Ruas Jalan a Di Kabupaten Lebak,” J. Tek. Sipil Cendekia, vol. 1, no. 1, pp. 1-14, 2020, doi: 10.51988/vol1no1bulanjulitahun2020.v1i1.4.

[3] M. Jurusan, T. Sipil, F. Teknik, and U. Riau, “1) 2, 2,” vol. 4, no. 2, pp. 1-9, 2017.

[4] E. Rizkiawan, A. Setiawan, and S. J. Legowo, "Perencanaan Tebal Lapis Tambah ( Overlay ) Metode Pd T-05-2005-B Dan Metode SDPJL Pada Ruas Jalan," E-Jurnal MatriksTeknik Sipil. Univ. Sebel. Maret. Surakarta., pp. 623-631, 2017.

[5] D. Wahyudi, P. Pratomo, and H. Ali, “Analisis Perencanaan Tebal Lapis Tambah ( overlay ) Cara Lenduntan Balik Dengan Metode Pd T-05-2005-B dan Pedoman Interim No . 002 / P / BM / 2011 B," Jrsdd, vol. 4, no. 1, pp. 137-152, 2016.

[6] I. Setiadi and A. Setyawan, "EVALUASI NILAI KONDISI PERKERASAN JALAN NASIONAL DENGAN METODE PAVEMENT CONDITION INDEX (PCI) DAN METODE BENKELMAN BEAM (BB) (Studi Kasus: Ruas Jalan Pakem-Prambanan)," vol. d, p. $1265,2017$.

[7] R. A. Saputro, "Perencanaan Tebal Perkerasan Lentur Pada Ruas Jalan Raya Krikilan Drioyorejo," pp. 1-11, 2021, [Online]. Available: http://repository.untagsby.ac.id/id/eprint/10488\%0Ahttp://repository.untag-sby.ac.id/10488/3/BAB 2.pdf.

[8] A. Y. Isnaini, L. B. Suparma, and S. H. T. Utomo, "Perancangan Perkerasan Jalan Lingkar Kota Kabupaten Wonogiri," J. HPJI, vol. 5, no. 2, pp. 119-128, 2019, doi: 
10.26593/jh.v5i2.3372.119-128.

[9] J. Pattipeilohy, W. Sapulette, and N. M. Y. Lewaherilla, "Perencanaan Tebal Perkerasan Lentur Pada Ruas Jalan Desa Waisarisa - Kaibobu,” Manumata Vol 5, No 2, vol. 5, no. 2, pp. 56-64, 2019.

[10] O. Pembuatan et al., "Optimalisasi Pembuatan Peta Kontur Skala Besar Menggunakan Kombinasi Data Pengukuran Terestris Dan Foto Udara Format Kecil," J. Geod. Undip, vol. 8, no. 1, pp. 180-189, 2019.

[11] F. D. Rassarandi, "Pemetaan Situasi dengan Metode Koordinat Kutub di Desa Banyuripan, Kabupaten Klaten," J. Integr., vol. 8, no. 1, pp. 50-55, 2016.

[12] KemenPUPR, MANUAL DESAIN PERKERASAN JALAN (REVISI 2017) Nomor 02/M/BM/2017, Jakarta: KemenPUPR, 2017. 